\title{
Konkurenční výhoda manažerského účetnictví
}

\author{
(Diskuse k článku Kaplan, Robert S.: The Competitive Advantage of Management \\ Accounting. Journal of Management Accounting Research, 2006, roč. 18, č. 1, \\ s. 127-135.)
}

Jana Fibírová*

Obsah článku „Konkurenční výhoda manažerského účetnictví“ je pro čtenáře zajímavý jak stručným připomenutím základního (ve smyslu historického) prrínosu dvou moderních nástrojů řízení $\mathrm{ABC}$ a $\mathrm{BSC}^{1}$, a to jejich samotným autorem R. S. Kaplanem, tak i inspirací $\mathrm{k}$ polemice s některými uváděnými argumenty. Autor článku, harvardský profesor Robert $\mathrm{S}$. Kaplan, patří bezesporu $\mathrm{k}$ jedněm $\mathrm{z}$ nejznámějších a nejuznávanějších ekonomů druhé poloviny 20. a počátku 21.století. Hlavními tématy, kterým se věnoval ve své výzkumné, pedagogické i konzultační činnosti, jsou nástroje řízení nákladů, řízení výkonnosti, implementace strategie.

I když R. S. Kaplana není nutno odborné veřejnosti představovat, připomeňme pro úplnost, a to zejména i s ohledem na téma článku, alespoň ty jeho nejznámější díla. Publikace Relevance Lost: The Rise and Fall of Management Accounting z roku 1987 je považována za důležitý mezník ve vývoji manažerského účetnictví. Na ni navazovalo několik publikací věnovaných Activity Based Costing a systému řízení nákladů (Implementing Activity-Based Cost Management: Moving from Analysis to Action s R. Cooperem a L. S. Maiselem (1992), Cost and Effect: Using Integrated Cost Systems to Drive Profitability and Performance s R. Cooperem (1998), Design of Cost Management Systems s R. Cooperem (1998), Time-Driven Activity-Based Costing: A Simpler and More Powerful Path to Higher Profits s R. S. Andersonem z roku 2007). Koncepci řízení Balanced Scorecard, jíž je spolu s Davidem Nortonem tvůrcem, věnoval R. S. Kaplan několik publikací. První z nich, The Balanced Scorecard: Translating Strategy into Action (1996), byla přeložena do 22 jazyků (včetně češtiny), v roce 2001 získala ocenění od Americké účetní asociace za svůj př́nos pro praxi. Dále The Strategy-Focused Organization: How Balanced Scorecard Companies Thrive in the New Business Environment (2000), Strategy Maps: Converting Intangible Assets into Tangible Outcomes (2004), Alignment: Using the Balanced Scorecard to Create Corporate

\# Článek je zpracován jako jeden z výstupů výzkumného projektu Rozvoj účetní a finanční teorie a její aplikace $v$ praxi z interdisciplinárního hlediska s registračním číslem MSM6138439903.

* Prof. Ing. Jana Fibírová, CSc. - profesorka; Katedra manažerského účetnictví, Fakulta financí a účetnictví, Vysoká škola ekonomická v Praze, nám. W. Churchilla 4, 13067 Praha 3; <fibirova@vse.cz>.

1 Anglické zkratky ABC a BSC jsou velmi rozšířené jak mezi teoretiky, tak i v hospodářské praxi, používají se bez překladu. Pouze pro úplnost uved'me plné názvy a stručné vysvětlení.

- Metoda kalkulace dílčích aktivit (Activity Based Costing, ABC) byla jedním z prvních nástrojů, který $\mathrm{v}$ polovině 80. let minulého století reagoval na změny v podnikatelském prostředí. Její uplatnění se stalo základem pro další rozvoj využití principů řízení na základě dílčích aktivit (Activity Based Management, $\mathrm{ABM})$, obdobně i rozpočtování podle dílčích aktivit (Activity Based Budgeting, $\mathrm{ABB}$ ).

- Koncepce Balanced Scorecard (BSC) byla nejprve pouze systémem „vyvážených“ (balanced) ukazatelů výkonnosti podniku (scorecard), který se posléze stal základem celé koncepce strategického řízení, popsaným a vysvětleným v již zmíněné knize Roberta Kaplana a Davida Nortona: The Balanced Scorecard: Translating Strategy into Action, z roku 1996. Tato koncepce byla velmi positivně přijata širokou odbornou veřejností a postupně se stala inspirací pro konkrétní změny systému řízení podniků $\mathrm{v}$ praxi. 
Synergies (2006). V tomto roce 2008 je připravena k vydání publikace The Execution Premium: Linking Strategy to Operations for Competitive Advantage.

Autor v článku stručně rekapituluje nejdůležitější výsledky a přínosy své dlouhodobé vědecké a konzultační činnosti. Explicitně přitom zmiňuje zejména metodu $A B C$ a koncept řízení BSC. Klade si otázku (která je skryta i v samotném názvu článku) - jaký přínos má pro praxi ekonomická teorie v porovnání s manažerským účetnictvím a zda metody $\mathrm{ABC}$ a BSC změnily závěry ekonomické teorie. Před argumentací či úvahou nad názory autora uved'me ve stručnosti jeho myšlenky $\mathrm{z}$ textu, s odlišením kurzivou. Z textu článku jsou vybrány pouze ty části, které jsou předmětem diskuse.

\section{Vztah ekonomické teorie a manažerského účetnictví}

„Zlepšení, která přinášejí nástroje manažerského účetnictví - ABC a BSC umožňují rídicím pracovníküm dosáhnout pomocí analytických nástrojů souladu v rízení podniku a zabránit tak chaosu a disproporcím vlivem individuálnich zájmů. Implementace těchto nástrojů ř́zení je sice drahá, ale prokazuji svoji schopnost vytvářet vyšši hodnotu než jsou jejich náklady, a to prostřednictvím vytvoření a predání (komunikace) správných informací, které ovlivňuji rozhodování tisiců zaměstnanců a desitek podniků o produktech, procesech, zákaznicich a transakcích. ABC s BSC jsou dva nové systémy manažerského účetnictví, které zasahuji do historie podnikání, do literatury o strategii, jejího směrování (,,aligning“), dosažení konkurenčních výhod. .....Proto, aby byl podnik úspěšný potřebuje úsilí a nasazení svých zaměstnanců. Manažerské účetnictví není pouze nástrojem pro rídicí pracovníky, mělo by svými informacemi ovlivňovat rozhodování všech zaměstnancủ. Není možné předpokládat, že pouze vedouci pracovníci maji řešit složité otázky bez rozsáhlého instrumentária řizení vlastní činnosti podniku. Kromě toho, že informace jsou důležité pro sestavení plánu, řizení činnosti, komunikaci, ovlivňuji současně i vlastní jednání lidí (zaměstnancü) tím, že jsou seznámeni s cíli podniku a s tím, jak mohou prispět $k$ dosažení jeho úspěchu.

Argumentem ke kritice, že empirický výzkum manažerského účetnictví nedostatečně ověruje ekonomickou teorii je poznání, že pro ověrení přínosu a využitelnosti vědních disciplin je důležitá schopnost aktivně měnit skutečný průběh činnosti podniku, nikoliv pouze predpovídat její vývoj. “

Vyjádření autora týkající se vlastního významu informací manažerského účetnictví pro řízení podniku není potřebné komentovat. Správnost tohoto pojetí je ověřena jak v oblasti teoretické (je přijato ve většině standardních učebnic manažerského účetnictví), tak i v oblasti praktické (stále širší aplikací ABC i BSC v podnikové praxi). Inspirací k diskusi je však otázka vztahu manažerského účetnictví a ekonomické teorie.

V odpovědi na otázku proč zkoumáme manažerské účetnictví, jaký je jeho přínos, se teoretické názory různí ${ }^{2}$. Hlavní proud se shoduje $v$ tom, že předmětem zájmu teorie v manažerském účetnictví je rozpoznání a vysvětlení příčin a důsledků, vztahů mezi nimi, s cílem nalézt konkrétní podobu informační podpory pro ř́zení. Od teorie a výzkumu

2 Obecným otázkám manažerského účetnictví je věnována řada článků v odborných publikacích, např́klad v Accounting, Organization and Society, Contemporary Accounting Research, Academy of Management Review, The Accounting Review, European Accounting Review, Journal of Accounting Research, Journal of Management Accounting Research, Accounting, Auditing and Accountability Journal,... Mezi autory, kteří se těmto otázkám věnují, jmenujme alespoň ty nejznámější - Hopwood (2002)., Ittner (s Larcker 2001, 2002; s Larcker a Lanen, 2002; s Larcker a Meyer, 2003), Lee (1999; s Williamsem, 1999), Lukka a Mouritsen (2002), Otley (1999), Zimmerman (2001) 
manažerského účetnictví se očekává, že bude někým využita, aby se něčeho dosáhlo. Manažerské účetnictví by mělo poskytovat vysvětlení toho, co je užitečné pro manažery. Teorie manažerského účetnictví by měla pomáhat odpovědět na otázky - jaké metody by měly být aplikovány, $\mathrm{v}$ jakých podmínkách, jak změnit manažerské účetnictví? Hlavním př́nosem teorie manažerského účetnictví je nalezení způsobů jejich aplikace v praxi.

Na rozdíl od ekonomické teorie, která se zabývá poznáním obecně platných zákonitostí, je manažerské účetnictví aplikační ekonomickou disciplinou. S měnícími se požadavky řízení se vyvíjí a mění využití informací manažerského účetnictví. Historicky se vyvíjí jejich funkce z pouhého „registrátora“ (s těžištěm na evidenci a kontrolu skutečného vývoje, př́pravu rutinních zpráv) k funkci „,navigátora“ (s těžištěm na interpretaci porovnání předpokládaného a skutečného vývoje, přijetí opatření, včetně aktivní účasti řídicích pracovníků na řízení, koordinaci cílů vrcholového řízení s motivací řídicích pracovníků na nižších úrovních vnitropodnikového řízení,...). Dynamické tržní prostředí vyžaduje od informační podpory řízení (manažerského účetnictví) vyhledávání problémů skutečného vývoje, zpochybnění stávajících systémů, hledání konstruktivních řešení orientovaných na budoucnost, vytváření systémů včasného rozpoznání rizik. Manažerské účetnictví by mělo plnit funkci „inovátora“, konzultanta managementu.

Ekonomická teorie a manažerské účetnictví jsou dvě odborné discipliny, které se zásadně liší svým předmětem zájmu. Jejich postavení není rivalitní či konkurenční, ale ve styčných bodech svého zájmu se vzájemně podporují. Není-li na jedné straně úkolem manažerského účetnictví ověřit ekonomickou teorii, jak autor v článku konstatuje, není na straně druhé předmětem zájmu ekonomické teorie aktivně ovlivňovat skutečný průběh činnosti podniku. Přínos ekonomické teorie by měl být posuzován jinými kritérii než přínos aplikačních disciplin jako je manažerské účetnictví.

\section{Metoda ABC opravuje chyby ekonomické teorie}

„Metoda ABC prohlubuje poznání o průběhu fundamentálních křivek nabídky a poptávky $z$ ",teorie firmy“, vyučované v každém předmětu mikroekonomie. Křivka nabidky (nákladů) zobrazuje zvyšování nákladů spojených s rostoucí výrobou homogenního produktu. Je zřejmé, že pouze málo firem, pokud vỉbec nějaké, vytvář́ pouze jeden produkt. .... Metoda ABC odhalila mnohem jasněji základni ekonomický problém firem s rozsáhlou sortimentní nabidkou výrobků, pro zákaznicky odlišné trhy a poskytla pojmový aparát a analýzu př́činných souvislostí pro vysvětlení významné nehospodárnosti rostoucího rozsahu činnosti zkoumaných firem, které rostly rozšiřováním nabídky výrobků, služeb, rostoucímu množství zákazníků. Až do té doby, než metoda ABC rozložila tzv fixní náklady do specifických položek zdrojů požadovaných individuálními objednávkami, výrobky, službami, zákazníky a distribučními kanály, nebylo možné vysvětlit proč náklady, které byly považovány za fixní se nejen neméní, ale v mnoha př́padech dokonce rostou rychleji než objem výkonü. Model ABC podstatně rozšiřuje teoretické znalosti o průběhu křivky nákladů, která vystihuje ekonomické zákonitosti v podnicich se širokým sortimentem a trhy. Model ABC tak predstavuje $i$ významný posun $v$ našem porozuměni hospodárného průběhu nákladů firem s komplexní činností. Zároveň to znamená, že manažerské účetnictví umožňuje lépe než ekonomická teorie poznat ekonomický systém moderních podniků, jejich struktury a procesů.

ABC pouze nezobecňuje poznatky nákladové křivky, ale opravuje chyby v teoretických předpokladech jejího průběhu. Teoretikové vysvětlují nelineární průběh nákladové křivky substituci kapitálu (přesněji vyjádřeno technického vybavení) a práce (mzdových nákladů). 
Linearita modelu $A B C$ se zdá být zjednodušením vporovnání s nelineárním modelem. Zásadním rozdilem je však to, že ABC rozlišuje mezi měrením spotřeby zdrojů a jejich použitím, a opravuje tak nesprávné určení průběhu teoretické nákladové funkce. I když vynaložené náklady spotřeby zdrojů mohou mít nelineárni průběh s rostoucím množstvím výkonů, náklady použití zdrojů jsou lineární.

Linearita použití zdrojů poskytuje základnu pro time-driven-activity-based costing, tedy nejnovějši reformulaci ABC. S využitím této time-driven modifikace potřebuji analytici kalkulovat pouze dvě množství: náklady na zajištěnou kapacitu (supplying capacity), zpravidla vyjádřenou v celkovém počtu hodin, a množství použité (spotřebované) kapacity na transakci nebo aktivitu, která je vykonána. Množství zdrojů závisí lineárně na objemu a mixu rozdilných typů vykonávaných aktivit. Tato formulace měrení nákladů zdrojů použitých na výrobky, služby a zákazníky je mnohem přesnějši a vhodnějši pro vyjádření a řízení ekonomiky podniků než komplexní ekonomické nelineární funkce, které jsou primárně použity, možná výhradně, pro vysvětlení agregovaných dlouhodobých informací napříč obory.

Aplikace predpokladů $A B C$ vedla $k$ tomu, že všechny náklady jsou variabilní. Toto by však nebylo přesné pripisovat metodě ABC, mnohem více je však nákladi̊ variabilních ně̌ konvenční myšlení předpokládalo.

Napríklad jeden stroj v malém prostoru je fixním nákladem, ale 130 strojů ve velkém prostoru je variabilním nákladem - je to poptávka po strojním času, která nemůže být zvládnuta jedním strojem, ale 50-ti. Kapacita je dělitelná. Každý podnik pečlivě zvažuje své vybavení zdroji, které vyhovuje poptávce po jejich využití. Podobná situace je u stanovení množství pracovníkù v call centrech, účetnich vodděleni pohledávek, nebo voddèleni IT a personálního ř́zení. Pro přesvědčivé a ekonomické vysvětlení množství zdrojů vynaložených pro tato oddělení je to, že byly pořizeny pro vyřizení poptávky po nich. “"

„Time-driven“ ABC model zjištuje kapacitu každého oddělení či procesu a určuje náklady této kapacity ve vztahu k objemu a struktuře vykonávané práce. Pokud vlivem průběžného zdokonalení a racionalizace výrobkových řad, objednávek, zákazníků, společnost snižuje poptávku po práci v těchto různých odděleních a procesech, model ABC určuje zdroje, které jsou potřebné do té doby, než ř́dici pracovníci přesunou zdroje nebo jejich rízení mimo společnost. Náklady se stávaji variabilní vlivem informací a ř́zením činnosti, nikoliv automaticky „v dlouhém časovém obdobi". Porozumění prostřednictvím ABC je fundamentální po ř́zení hospodárnosti společnosti. “

Metoda $\mathrm{ABC}$ představuje bezesporu významný posun v rozpoznání příčinných souvislostí vzniku nákladů (Král aj., 2005). Tato metoda umožnila na základě zdokonalené kalkulace nákladové náročnosti produktů a zákazníků zjistit, že strategie diferenciace sortimentu, na kterou se řada firem v minulosti orientovala, se ukázala jako chybná. Snaha přizpůsobit produkty individuálním požadavkům zákazníků, důraz na zvyšování kvality a často i na zkracování dodacích lhůt, znamenají zvyšování rozsahu a nákladů některých činností (např́klad logistiky, komunikace, kontroly jakosti, plánovacích aktivit,...).Vyspělé společnosti uvádějí, že jejich prodejní a marketingové náklady rostou třikrát rychleji než náklady na práci a materiál (Doyle, 2006). Metoda $A B C$ ve svém důsledku tak ovlivnila nejen př́stupy a nástroje ř́źzení nákladů, ale i celkovou strategii podniků. V tomto směru jsou poznatky uvedené v článku nejen stručnou a srozumitelnou rekapitulací podstaty a př́nosu metody $\mathrm{ABC}$, ale i uznáním jejího významu pro řízení konkurenceschopné firmy. 
Je-li na jedné straně považováno dokonalejší rozpoznání příčinných souvislostí vývoje nákladů pomocí kalkulace dílčích aktivit za zásadní posun a změnu ve vypovídací schopnosti informací manažerského účetnictví, v účinnosti používaných nástrojů hodnotového řízení (nejprve kalkulací, později i rozpočtů, vnitropodnikových cen), neznamená to zároveň na straně druhé, že manažerské účetnictví umožňuje lépe než ekonomická teorie poznat ekonomický systém moderních podniků. ${ }^{3}$ Informace poskytované metodou ABC umožňují lépe řídit podnik, konkrétněji vyjádřeno, stanovit „správnou“ strategii a využít motivačně účinné nástroje pro její implementaci.

\section{Překonání teoretické nákladové křivky pro homogenní produkty}

Metoda $\mathrm{ABC}$ však zároveň nemění základní teoretické poznatky o průběhu nákladových křivek homogenních produktů. Právě vysvětlení pomocí metody $\mathrm{ABC}$, proč náklady, které byly považovány za fixní se nejen nemění, ale mohou růst rychleji než objem výkonů (zejména náklady obslužných, informačních, plánovacích, kontrolních aktivit), vedlo k poznání, že naopak manažerské účetnictví přistupovalo velmi zjednodušeně k vymezení předmětu kalkulace (kalkulační jednice). Při členění výkonů v manažerském účetnictví je nutno věnovat pozornost nejen odlišnosti základní věcné podstaty vytvářených výkonů (s rozlišením skupin, druhů a jakostí výkonů), ale i podrobnějšímu rozlišení výkonů podle toho, jakým konkrétním zákazníkům a za jakých obchodně platebních podmínek se na trhu prodávají (Fibírová - Šoljaková - Wagner, 2007). Požadavky zákazníka na včasnost a periodicitu dodávek, rychlost odezvy na změny v jeho konkretizované poptávce, významně ovlivňují nejen náklady na vlastní tvorbu výkonů (konkrétního objemu a sortimentní struktury), ale i náklady vázaného kapitálu (především výši „,pohotovostních“ zásob výkonů připravených $\mathrm{k}$ prodeji).

Metoda $\mathrm{ABC}$ v této souvislosti proto spíše potvrdila obecnou správnost teoretického modelu nákladové křivky. Na první pohled „nová“ zákonitost vývoje nákladů, spočívající v jejich růstu i při klesajícím objemu výkonů, byla metodou $\mathrm{ABC}$ vysvětlena změnou struktury sortimentu. Tato proměnná není v teoretickém modelu pro homogenní produkt zahrnuta. Není tedy chybný teoretický model, ale chybné bylo jeho použití pro strukturu ve skutečnosti nákladově nehomogenních výkonů. Je otázkou, zda právě strategie důsledného zúžení zákaznického a produktového portfolia, politika racionalizace produktů (Doyle, 2006) ${ }^{4}$, není potvrzením obecné platnosti teoretické nákladové křivky. Pro dosažení konkurenceschopnosti podniku je nezbytné zajistit hospodárné vynakládání nákladů v procesu tvorby výkonů, tzn. vynakládat náklady přiměřené dosahovaným výnosům.

3 Jak již bylo v této polemice uvedeno, odlišnosti obsahového zaměření ekonomické teorie a aplikovaných disciplin by neměly být použity k vzájemnému porovnávání jejich důležitosti, ale naopak k hledání společných styčných bodů. Jejich vztah není konkurenční, ale vzájemně se doplňující.

4 V této souvislosti podniky používají tzv. testy „ukončení“ Jejich cílem je zjistit, zda firma investuje více úsilí do toho, aby „dělala věci správně“, nebo do toho, aby „dělala správné věci“. Takový postup může přinést výsledky v podobě:

- vyřazení nepotřebných variací produktů a značek na některých trzích, což umožní zákazníkům snáze porozumět výběru při nákupu a snížit marketingové výdaje spojené s produkty;

- zrušení nevhodných propagačních nabídek jako „kupte jeden, dostanete druhý zdarma“;

- sjednocení způsobu uspořádání zákaznických služeb na jednotlivých regionálních trzích. Služby zákazníkům tak mohou být prováděny efektivněji na více trzích zároveň;

- racionalizace způsobu stanovování cen pomocí minimalizace množství ceníků (tj. snížení jejich počtu), a dále zavedením elektronického př́jmu objednávek, které významným způsobem minimalizuje množství chyb v objednávkách. 


\section{Odlišnost způsobu členění fixních a variabilních nákladů v ekonomické teorii a v praxi}

V článku R. S. Kaplana jsou dále diskusní i ta konstatování, která se týkají přínosu metody $\mathrm{ABC}$ pro rozlišení fixních a variabilních nákladů v praxi, a s tím související kritika využitelnosti předpokladů průběhu nákladové křivky ekonomické teorie.

Zjednodušení teoretické nákladové křivky, související se způsobem rozlišení nákladů na fixní (v podobě odpisů technického vybavení) a variabilní (v podobě mzdových nákladů) je v praxi překonáno již od konce 60.let, tedy řádově o 20 let dř́ve než byla vyvinuta metoda $\mathrm{ABC}$. Již v této době přestalo potřebám řízení podniku vyhovovat agregované rozlišení na fixní a variabilní náklady, nejčastěji provedené s využitím matematicko statistických metod regresní a korelační analýzy, která předpokládala, že fixní náklady jsou konstantní, že nedochází $\mathrm{k}$ jejich úspoře či překročení. I $\mathrm{v}$ praxi byly do konce 60.let fixní náklady zjednodušeně ztotožňovány zejména s náklady na užívání dlouhodobých aktiv (časové odpisy, nájemné).

Od počátku 70. let, spolu s významným nárůstem podílu tzv. vyhnutelných fixních nákladů, se v praxi začalo používat podrobné analytické členění fixních a variabilních nákladů prímo v účetnictví (v manažerském účetnictví), na analytických nákladových účtech, podle odlišné prŕčiny vzniku těchto nákladů. Při tomto členění je nejdůležitější to, jakým způsobem (jakými nástroji a v souladu s jakými kritérii) je možno náklady řídit. Pokud je možno úkol ve vynaložených nákladech stanovit normou spotřeby nákladů na konkrétně vymezenou naturální jednotku výkonu, nebo normativem na skupinu výkonů, dávku, jedná se o náklady variabilní. Pokud jsou náklady stanoveny v celkové výši jako limit na určité období, pak jsou tyto náklady ř́zeny jako fixní.

Odlišný způsob stanovení nákladového úkolu vychází z odlišné předpokládané příčiny vynaložení variabilních a fixních nákladů, z odpovědi na otázku - zda sledovaná nákladová položka je vyvolaná výkonem či časem (obdobím).Variabilní náklady se opakovaně vynakládají s měnícím se množstvím výkonů (jsou množstvím výkonů spotřebovány). Naproti tomu fixní náklady se vynakládají vždy po uplynutí časového období, v jehož rámci zajišstují určitou kapacitu (jsou to náklady „,potenciální“, umožňující využití). Dle skutečně vytvořeného množství výkonů jsou pak fixní náklady v různém stupni využívány (nevyužívány) (Fibírová - Šoljaková - Wagner, 2007).

Tím, že metoda $A B C$ významně přispěla hloubce procesu rozpoznání příčinných souvislostí vzniku nákladi̊, je možno s využitím této metody v manažerském účetnictví rozpoznat mnohem širší rozsah variabilních nákladů než umožňovalo konvenční myšlení. Analýza $\mathrm{ABC}$ využívá členění nákladů podle „úrovně vztahové veličiny“, která je př́ičinou jejich vzniku. Z toho hlediska se rozlišují aktivity vyvolané jednotkou výkonu (tradiční jednicové náklady - jednicový materiál, jednicové mzdy, dále i na kontrolu výrobků), výrobní dávkou (prŕíprava výrobní dávky, seřízení strojů pro konkrétní dávku), druhem výkonu (vývoj výkonu, propagace výkonu), činností podniku jako celku (správní náklady). Je však nutno důsledně rozlišovat, zda se při této analýze jedná o aktivitu ve smyslu př́činy vzniku nákladů (nákladů variabilních) či pouze o vztahovou veličinu ve smyslu kalkulačním. Tedy pouze pro přiřazení (propočet) nákladů výkonu (včetně fixních nákladů). 


\section{Time-Driven-Activity-Based Costing}

Zastavme se $v$ této souvislosti $u$ argumentace R.S.Kaplana uvedené při použití TimeDriven-Activity-Based Costing, jako nejnovějšího metodického řešení metody $A B C$. Jedná se ve všech uvedených prŕkladech vskutku o variabilní náklady, jak autor uvádí (náklady na strojní vybavení, mzdové náklady pracovníků v call centrech, voddělení pohledávek, v oddělení IT či odděleních personálního řízení)?

V praxi je ověřeno, že pro potřeby hospodárného vynakládání nákladů je vhodné řídit mzdové náklady výkonných pracovníků útvarů jako náklady variabilní. Časová mzda je $\mathrm{v}$ tomto př́ípadě chápána jako smluvně dohodnutý, stabilní př́ijem pracovníka (výdaj peněz), který je ve sledovaném období odměnou za předpokládaný objem výkonů. Ve sledovaném období (například půlročním či ročním) bývá přitom typické kolísání výkonu pracovníků $\mathrm{v}$ kratších časových úsecích (měsíčních). Proto, aby bylo možno naplnit kritéria členění nákladů na variabilní a fixní v manažerském účetnictví je přitom nezbytné, aby konkrétní aktivity, které pracovníci provádějí, bylo možné měřit a vyhodnocovat. S využitím informací o předem stanovené nákladové náročnosti aktivit a o jejich skutečně provedeném objemu je možno zjistit, zda by měl být počet pracovníků útvaru zvýšen či naopak snížen.

Pokud se však jedná o náklady na strojní zařízení, je otázkou, zda př́klad přizpůsobení kapacity snižováním či zvyšováním počtu jednotlivých strojů je u takovýchto nákladů v praxi typický. U specializovaných technologických zařizení, individuálně pořizovaných pro konkrétní proces tvorby výkonů, je pro rozlišení těchto nákladů na variabilní a fixní důležitý spíše způsob opotřebení těchto zařízení. Pokud je základní př́ičinou opotřebení dlouhodobého aktiva, během předpokládané doby jeho použitelnosti, čas (morální opotřebení), měly by být použity časové odpisy (jedná se o fixní náklad). Pokud je u konkrétního aktiva možno předpokládat, že jeho použitelnost skončí po vytvoření určitého počtu výkonů, měly by být použity výkonové odpisy (jedná se o variabilní náklad).

Při použití metody Time-Driven-Activity-Based Costing je nutno rozlišovat, zda náklady na časovou jednotku zajištěné kapacity jsou vskutku variabilní, jsou při použití spotřebovány, či naopak fixní, a jsou při použití na transakce či aktivity pouze v konkrétní míře využívány. Pokud se u fixních nákladů liší skutečné využití kapacity v porovnání s plánovaným (standardním) využitím, vzniká rozdíl mezi kalkulovanými plnými náklady a skutečně vynaloženými náklady (za jinak stejných okolností, to znamená, že nepředpokládáme absolutní úsporu či překročení nákladů). Tento rozdíl (nevyužité, lépe využité - neuhrazené (underabsorbed), více uhrazené (overabsorbed) náklady) kvantifikuje vliv skutečného využití fixních nákladů na zisk. Pro řídicí pracovníky jsou neuhrazené (více uhrazené) fixní náklady důležitou informací o tom, jaká výše zisku (ztráty) je způsobena rozdílným využitím kapacity (v porovnání s předem stanovenou výší). Samostatnou otázkou přitom je, zda je možné a jakým způsobem tento vliv kompenzovat (upravit rozpočet), a tím se přiblížit splnění cílů ve vývoji zisku stanovených plánem.

Je zřejmé, že vypovídací schopnost kalkulace plných nákladů, která bývá často předmětem kritiky (,statická“ kalkulace fixních nákladů na jednotku výkonu při plánovaném využití kapacity), poskytuje potřebné informace pro ř́zení nákladů (přijetí opatření na kompenzaci vlivu nevyužitých či lépe využitých fixních nákladů). Kalkulace tvoří v moderně řízeném podniku systém, jehož důležitou součástí je i variantní využití kalkulace plných a variabilních nákladů, jejich vhodné kombinace. 


\section{Linearita modelu ABC}

Argumenty R.S.Kaplana týkající se linearity modelu ABC jsou stručným vysvětlením předpokladu o průběhu vývoje variabilních nákladů při řízení v praxi. Lineární model se pro vyjádření vývoje nákladů (a výnosů) ve vztahu k objemu výkonů využívá v manažerském účetnictví již historicky (od počátku 20.století). Tento model bývá často charakterizován jako zjednodušení, nepřesné zobrazení, průběhu nelineárního modelu ekonomické teorie. Toto vysvětlení není zcela správné. Ekonomická teorie analyzuje vývoj nákladů na celkový teoreticky možný rozsah kapacity zajištěné fixními náklady. Uvažuje úspory z rozsahu na vstupech (ve spotřebě materiálu, práce), a tím i změny průměrných variabilních nákladů.

Při analýze nákladů na úrovni podniku v rámci tzv. úloh na existující kapacitě se vychází z toho, že podnik disponuje určitou výší a strukturou aktiv, lidských a dalších zdrojů, které určují horní limit rozsahu činnosti. Na druhé straně se běžně předpokládá stabilizovaný průběh činnosti a jeho kontinuální pokračování, existující zákaznická struktura, které zajišt’ují dolní limit rozsahu činnosti. Reálný rozsah činnosti tak osciluje mezi těmito limity např́íklad v řádu několika procent.

Při aplikaci lineárního modelu v manažerském účetnictví se nepředpokládají zásadní změny, které by výrazně ovlivnily objem a strukturu aktiv a znamenaly úspory z rozsahu. Předpoklad lineárního vývoje variabilních nákladů vyjadřuje jak základní tendenci vývoje nákladů podložené analýzou jejich skutečného vývoje $\mathrm{v}$ minulých obdobích, tak zejména vyjadřuje způsob stanovení nákladového úkolu (předem stanovených nákladů) pro další období. Pro řízení je lineární vývoj nákladů vyjádřením cíle, kterého by mělo být dosaženo. Splnění předem stanovených nákladů (norem, normativů, limitů) je důležitou informací o předvídatelnosti vývoje nákladů, o kvalitě nástrojů řízení hospodárnosti (kalkulací a rozpočtů) (Drury, 2004).

\section{Poptávková křivka ekonomické teorie by měla zahrnout více proměnných než pouze cenu}

„Jinou křivkou, která je základní výbavou mikroekonomické teorie je klesajici křivka poptávky, která představuje rostouci množství zboží, které spotřebitelé nakupují při klesajicích cenách. Cena je zvlášt důležitá v rozhodování o nákupu, ale kromě pro vysoce konkurenční komodity, s malou možností jejich diferenciace, to není jediný faktor ovlivňující cenová rozhodování. Mnoho společností se snaži najít zákazníky, kteři jsou ochotni platit podstatně vyšší ceny, dokonce $i$ za standardní produkty a služby, pokud je nákup snadný a rychlý.

Když jezdím každý večer domů a mijím stanici Mobil prodávajici benzin, jednu z nejvíce konkurenčních komodit, nakupuji za cenu minimálně o 0,10 USD vyšši než je u nejbližši benzinové stanice. Za vyšš́ cenu nakupuji benzin u Mobil stanice, stejně jako řada dalšich zákazníků, protože je možno ho načerpat u více stojanů, tedy nikdy nečekám, je to rychlý nákup, sčistými a bezpečnými toaletami. Naproti tomu, pokud bych nakupoval u ,discount“ stanic, vím, že bych ušetřil, ale musel bych čekat, platit v hotovosti, s využitím nižši kvality služeb.

Poptávková křivka, která charakterizuje rozhodováni spotřebitelů při nákupu by měla zahrnout vice proměnných než pouze cenu. BSC měř́ vztah naplnění cílů zákazníka a ceny, která má zákazníka získat, udržet a prohloubit vztah s cílovými zákazníky. Tyto informace 
manažerského účetnictví jsou zobecněním závěrů poptávkové křivky z ekonomické teorie. To jasně modeluje di̊ležité faktory, včetně ceny, které ovlivňují rozhodování zákazníků. “

To, zda se ekonomická teorie potřebuje zabývat modelem vícekriteriální poptávkové funkce, jak R.S.Kaplan v článku navrhuje, je otázkou př́nosu takovéhoto modelu, posunu teoretických znalostí. Ekonomická teorie $\mathrm{v}$ této souvislosti šla historicky trochu jiným směrem. Věnovala značnou pozornost platnosti podmínek dokonalé konkurence a rozpracování dalších modelů tržních vztahů (monopolistické, oligopolní, monopolní konkurence), ve kterých analyzovala širší souvislosti fungování trhu. Modifikace průběhu poptávkové křivky, modifikace pružnosti poptávky vlivem konkurence, známá jako zalomená křivka poptávky oligopolního trhu ${ }^{5}$, je toho konkrétním př́ikladem.

Obdobně jako v předchozích částech diskuse je i v této souvislosti otázkou, zda koncepce ř́zení BSC je přínosem pro ekonomickou teorii. Obecnými poznatky a nástroji řízení vztahů se zákazníky se zabývá marketing. BSC je v zákaznické perspektivě konkrétní aplikací především poznatků marketingu, nikoliv ekonomické teorie. Je návrhem informační podpory řízení, konkrétních kritérií a měřítek pro vyjádření stavu a vývoje konkurenční pozice podniku na trhu. Pro ekonomickou teorii nepřináší BSC nové poznatky. Popsaná zákonitost poptávkovou křivkou je stále platná. Příklad, který R.S.Kaplan v článku uvádí je potvrzením toho, jak na první pohled vysoce konkurenční produkt (benzin), je možno diferencovat doplňkovými službami (vyhovující způsob platby, úspora času zákazníka při nákupu, vyšší hygienická vybavenost, nabídka prodeje doplňkového zboží,...).

\section{BSC jako komplexní model řízení}

„Zdá se, že ABC a BSC se pro mnoho podnikư staly rutinními nástroji. Je zřejmé, že již bylo překonáno obdobi, ve kterém byla předmětem zájmu výzkumu otázka „proč “ a stala se jím otázka ,jak“. Otázkou je jak použivat tyto nástroje, aby byly př́stupné, efektivní a snadno použitelné, jaká je konkrétní podoba a organizační zásady, které vedou k úspěchu či naopak neúspěchu?

V současné době existuje celá řada studií o úspěšném či naopak neúspěšném zavedení inovativních nástrojů manažerského účetnictví. Tyto modely bohužel často vycházejí $z$ takových charakteristik společností, oborů činností, pro která je jednoduché ziskat data. Přitom je zřejmé, že měřitka v modelu by neměla být použita, protože jsou snadno dostupná. Při implementaci BSC by méla platit důležitá zásada - méli bychom měřit to, co chceme, nikoliv chtit, to co jsme schopni jednoduše měřit.

20-ti leté zkušenosti s úspěšnými a neúspěšnými implementacemi ABC a BSC prokázaly, že nejdi̊ležitějši vysvětlující proměnnou je kvalita vrcholového řizení firmy (leadership).

Napřiklad je možno porovnat zavedení ABC v General Motors a v Chrysler. Implementace $v$ Chrysler bylo úspěšnějši než v GM, protože byla vedena a prosazována CEO Robertem Eatone a generálním ředitelem Robertem Lutzem. Naproti tomu v General Motors, $k d e$ zaváděli ABC mnohem dř̀ve než v Chrysler, tento projekt nepřesáhl finanční oddělení, byl zavádèn jako „oficiálni" metodologie ř́zení nákladư, nestál v centru pozornosti a nikdy se nestal rozhodujíci pro uspořádání činností, jejich změnu. Odlišné vedení $A B C$ ve dvou společnostech má za sebou relativně dlouhou dobu pro vysvětlení odlišného prostoru.

5 Autorem modelu tzv. zalomené poptávkové křivky“ v podmínkách oligopolní konkurence je známý americký ekonom Paul M.Sweezy (1939). 
Uživatelem pro BSC je vyšši úroveň ř́zení, nikoliv finanční či IT oddělení. Role CEO je tak důležitá, že se projeví jak v úspěšné, tak neúspěšné implementaci BSC. Každý rok s Davidem Nortonem vyhodnocujeme okolo dvou desitek společností z celého světa, které dobře implementovaly BSC a podstatně (dramaticky) zvýšily svoji výkonnost. Ve všech těchto prípadech CEO vedl a prosazoval projekt BSC. Nikdy jsme neviděli vysoce úspěšnou implementaci BSC bez aktivního vedení CEO. V̌̌echny pokusy pro vysvětlení rozdilů úspěšných inovací manažerského účetnictví či ř́dicich systémů, takových jako ABC či BSC, by měly vždy ve své analýze zahrnovat kvalitu vedení. V opačném připadě je opomenut významný faktor. Controlleři (manažerští účetní) by měli mít jako partnery své kolegy, kteři se zabývají chováním organizace, nikoliv jen ekonomy a kolegy z finančních oddělení."

Poslední část článku R.S.Kaplana je vybrána nikoliv jako námět do diskuse, ale jako př́ležitost citovat myšlenky samotného tvůrce uznávaných moderních nástrojů řízení a předat tak i širší odborné veřejnosti tolik cenné praktické zkušenosti, které v naší praxi stále ještě chybí.

Pro úspěch nástrojů manažerského účetnictví v praxi (ABC), koncepce řízení (BSC), neexistuje univerzální recept. Pro každý konkrétní podnik je nezbytné budovat systém řízení, který je specifický nejen vlivem oboru činnosti podniku, jeho historie, ale především i schopností řídicích pracovníků, jejich přístupů k řízení. Zdůraznění role vrcholového vedení a týmové spolupráce při implementaci BSC je potvrzením toho, že se jedná o účinný nástroj koordinace řízení a komunikace ve firmě. Citace názorů R.S.Kaplana potvrzují, že implementaci BSC nemohou úspěšně zrealizovat pouze finanční útvary. Př́ínos BSC je v návrhu informační podpory komplexního řízení. Umožňuje propojit základní úrovně řízení (strategické, taktické, operativní), základní perspektivy řízení (nejčastěji členěné na finanční, zákaznickou, interních procesů a růstu), koordinovat cíle podniku jako celku se stanovenými úkoly hierarchicky nižších úrovní rízení (Kaplan - Norton, 2000).

\section{Závěr}

Metoda $\mathrm{ABC}$ představuje významný posun $\mathrm{v}$ rozpoznání prííčinných souvislostí vzniku nákladů. Její využití zvyšuje vypovídací schopnost manažerského účetnictví (kalkulačního systému, systému plánů a rozpočtů). Informace poskytované metodou ABC umožňují lépe ř́́dit konkurenceschopnost podniku, stanovit jeho strategii a využít motivačně účinné nástroje pro její implementaci. To však zároveň neznamená, že metoda $\mathrm{ABC}$ změnila obecné poznatky ekonomické teorie o průběhu a proměnných nákladové a poptávkové křivky.

Odlišnosti obsahového zaměření ekonomické teorie a aplikovaných disciplin by neměly být použity $\mathrm{k}$ vzájemnému porovnávání jejich důležitosti, ale naopak khledání společných styčných bodů. Jejich vztah by neměl být konkurenční, ale vzájemně se doplňující.

Při analýze nákladů ve vztahu $\mathrm{k}$ aktivitě $(\mathrm{ABC})$ je nutno důsledně odlišovat, zda se jedná o aktivitu ve smyslu příčiny vzniku nákladů (nákladů variabilních) či pouze o vztahovou veličinu ve smyslu kalkulačním, tedy pouze pro přiřazení (propočet) nákladů výkonu (včetně fixních nákladů). Kalkulace tvoří v moderně řízeném podniku systém, jehož důležitou součástí je i variantní využití kalkulace plných a variabilních nákladů, jejich vhodné kombinace.

Zdůraznění role vrcholového vedení a týmové spolupráce řídicích pracovníků při implementaci BSC je potvrzením toho, že se jedná o účinný nástroj koordinace řízení a komunikace ve firmě. Př́nos BSC je v zejména návrhu informační podpory komplexního 
řízení, umožňujícího propojit strategické, taktické a operativní řízení, a to ve všech základních průřrezech - perspektivách (finanční, zákaznické, interních procesů a růstu).

\section{Literatura}

[1] Cooper, R. - Kaplan, R. S. - Maisel, L. S. (1992): Implementing Activity-Based Cost Management: Moving from Analysis to Action. Montvale, Institute of Management Accountants, 1992.

[2] Cooper, R. - Kaplan, R. S. (1998): Design of Cost Management Systems. Englewood Cliffs, Prentice-Hall, 1999.

[3] Doyle D. (2006): Strategické ř́zení nákladů. Praha, ASPI, 2006.

[4] Drury, C. (2004): Management \& Cost Accounting. Florence, Thomson Learning, 2004.

[5] Fibírová, J. - Šoljaková, L. - Wagner, J. (2007): Nákladové a manažerské účetnictví, Praha, ASPI, 2007

[6] Hopwood, A. (2002): If Only There Were Simple Solutions, but There Aren't: Some Reflections on Zimmerman's Critique of Empirical Management Accounting Research. European Accounting Review, 2002, roč. 11, č. 4, s. 777-785.

[7] Ittner, C. D. - Larcker, D. F. (2001): Assessing Empirical Research in Managerial Accounting: A Value-based Management Perspective. Journal of Accounting and Economics, 2001, roč. 32, č. 1-3, s. 349-410.

[8] Ittner, C. D. - Larcker, D. F. (2002): Empirical Managerial Accounting Research: Are We Just Describing Management Consulting Practice. European Accounting Review, 2002, roč. 11, č. 4, s. 787-794.

[9] Ittner, C. D. - Larcker, D. F. - Lanen, W. N. (2002): The Association between ActivityBased Costing and Manufacturing Performance. Journal of Accounting Research, 2002, roč. 40 , č. 3, s. 711-727.

[10] Ittner, C. D. - Larcker, D. F. - Meyer, M. W. (2003): Subjectivity and the Weighting of Performance Measures: Evidence from a Balanced Scorecard. Accounting Review, 2003, roč. 78, č. 2, s. 725-758.

[11]Kaplan, R. S. - Anderson, S. R. (2007): Time-Driven Activity-Based Costing: A Simpler and More Powerful Path to Higher Profits. Boston, Harvard Business School Press, 2007.

[12] Kaplan, R. S. - Cooper, R. (1998): Cost and Effect: Using Integrated Cost Systems to Drive Profitability and Performance. Boston, Harvard Business School Press, 1998.

[13] Kaplan, R. S. - Norton D. P. (1996): The Balanced Scorecard: Translating Strategy into Action. Boston, Harvard Business School Press, 1996.

[14]Kaplan, R. S. - Norton D. P. (2000): Balanced Scorecard, Strategický systém měrení výkonnosti podniku. Praha, Management Press, 2000.

[15] Kaplan, R. S. - Norton D. P. (2000): The Strategy-Focused Organization: How Balanced Scorecard Companies Thrive in the New Business Environment. Boston, Harvard Business School Press, 2000.

[16] Kaplan, R. S. - Norton D. P. (2004): Strategy Maps: Converting Intangible Assets into Tangible Outcomes. Boston, Harvard Business School Press, 2004. 
[17] Kaplan, R. S. - Norton D. P. (2006): Alignment: Using the Balanced Scorecard to Create Corporate Synergies. Boston, Harvard Business School Press, 1996.

[18]Kaplan, R. S. - Norton D. P. (2008): The Execution Premium: Linking Strategy to Operations for Competitive Advantage. Boston, Harvard Business School Press, 2008.

[19] Kaplan, R. S. (1987): Relevance Lost: The Rise and Fall of Management Accounting. Boston, Harvard Business School Press, 1987.

[20] Kaplan, R. S. (2006): The Competitive Advantage of Management Accounting. Journal of Management Accounting Research, 2006, roč. 18, č. 1, s. 127-135.

[21] Král, B. aj. (2005): Manažerské účetnictví, Praha, Management Press, 2005.

[22]Lee, T. A. - Williams, P. W. (1999): Accounting from the Inside: Legitimizing the Accounting Academic Elite. Critical Perspectives on Accounting, 1999, roč. 10, č. 6, s. 867-895.

[23]Lee, T. A., (1999): Anatomy of a Professional Elite: The Executive Committee of the American Accounting Association 1916-1996. Critical Perspectives on Accounting, 1999, roč. 10 , č. 2, s. 247-264.

[24]Lukka, K. - Mouritsen, J. (2002): Homogenity or Heterogenity of Research in Management Accounting. European Accounting Review, 2002, roč. 11, č. 4, s. 805-811.

[25] Otley, D. T. (1999): Performance Management: A Framework for Management Control Systems Research. Management Accounting Research, 1999, roč. 10, č. 4, 363-382.

[26] Sweezy, P. M. (1939): Demand under Conditions of Oligopoly. Journal of Political Economy, 1939, roč. 47, č. 4, s. 568-573.

[27] Zimmerman, J. L. (2001): Conjectures Regarding Empirical Managerial Accounting Research. Journal of Accounting and Economics, 2001, roč. 32, č. 1-3, s. 411-427. 


\title{
Konkurenční výhoda manažerského účetnictví
}

\author{
Jana Fibírová
}

\begin{abstract}
ABSTRAKT
Metoda $\mathrm{ABC}$ a BSC umožňují lépe řídit podnik, stanovit strategii a využít motivačně účinné nástroje pro její implementaci. Metoda $\mathrm{ABC}$ představuje významný posun $\mathrm{v}$ rozpoznání př́ícinných souvislostí vzniku nákladů, nemění však zároveň základní teoretické poznatky o průběhu křivky nabídky (nákladů) a křivky poptávky. Zjednodušené rozlišení nákladů na variabilní a fixní navrhované ekonomickou teorií je v manažerském účetnictví překonáno již od konce 60.let, tedy mnohem dř́ve než byla vyvinuta metoda ABC. Odlišnosti obsahového zaměření ekonomické teorie a aplikovaných disciplin by neměly být použity k vzájemnému porovnávání jejich důležitosti, ale naopak k hledání společných styčných bodů. Jejich vztah by neměl být konkurenční, ale vzájemně se doplňující.

Klíčová slova: Kalkulace podle dílčích aktivit (ABC), Balanced scorecard (BSC), Křivka nabídky (nákladů); Křivka poptávky; Strategie řízení; Finanční a zákaznická perspektiva ř́zení; Hodnotová a naturální kritéria výkonnosti.
\end{abstract}

\section{The Competitive Advantage of Management Accounting}

\begin{abstract}
$\mathrm{ABC}$ and BSC methods enable to better manage the company set the strategy and use effective motivational instruments for its implementation. ABC method represents significant development in recognition of causality of cost origin. However, it doesn't change basic theoretical findings in behaviour of supply (costs) and demand curve. The simplified cost distinguishing between variable and fixed suggested by economic theory has become a thing of the past in the managerial accounting since late 60ties, i.e. much sooner before $A B C$ method has been developed. Divergence of content focus of economic theory and applied disciplines shouldn't be used for comparison of their importance but on the contrary for searching for common points. Their relationship shouldn't be competitive but complementary.

Key words: Activity based costing (ABC); Balanced scorecard (BSC); Supply (cost) curve; Demand curve; Management strategy; Financial and customer management position; Financial and physical performance criteria.
\end{abstract}

JEL classification: M490. 